\title{
Pattern Of Skin Diseases In A Rural Village Development Community Of Nepal
}

\author{
Shrestha $R^{1}$, Lama $L^{2}$, Gurung $D^{3}$, Shrestha DP ${ }^{4}$, Rosdahl $I^{5}$
}

${ }^{1,2}$ Clinical Tutor, Department of Dermatology, National Academy of Medical Sciences, Bir Hospital, Kathmandu, Nepal; ${ }^{3}$ Consultant Dermatologist, DI Skin Hospital and Research Center, Kathmandu, Nepal; ${ }^{4}$ Professor, Department of Dermatology \& Venereology, Institute of Medicine, Maharajgunj Medical Campus, Kathmandu, Nepal; ${ }^{5}$ Visiting Professor, Department of Dermatology, Kathmandu Medical College, Kathmandu, Nepal.

\section{Address for correspondence}

Dr. Dwarika P Shrestha

Department of Dermatology, IOM, Kathmandu, Nepal

Telephone: 5592217;

E-mail: drdpshrestha@gmail.com

\section{Citation}

Shrestha R, Lama L, Gurung D, Shrestha DP, Rosdahl I. Pattern of skin diseases in a rural village development community of Nepal. NJDVL 2014; 12(1): 41 - 44.

\begin{abstract}
Introduction: Skin diseases are a common cause of morbidity in Nepal as per the health services report. There is limited information on the prevalence and pattern of skin diseases in the community.

Objectives: This study was conducted to determine the pattern of skin diseases in a rural village development community of Nepal.

Material and methods: Two dermatologic health camps were conducted, during which, the villagers were examined by dermatologists. The skin diseases diagnosed were recorded in a proforma.
\end{abstract}

Results: There were 433 individuals examined and 359 (male-47.9\%; female-52.1\%) had skin disease identified clinically (camp prevalence$83 \%$ ). The age of patients ranged from 1 to 80 years (mean-24.5; $\mathrm{SD} \pm 15.9$ ), with majority in the age group of $10-19$ years. The most common skin disease category was eczemas (36.4\%), followed by infections (28.4\%), acne (22\%), pigment disorders (34\%) and urticaria $(12.3 \%)$.

Conclusion: Skin diseases were common in the community. The five most common Skin disease categories were eczemas, infections, acne and pigment disorders were the more common conditions.

Keywords: Acne, Eczema, Infection, Pattern of skin diseases, Pigment disorder, Village development community.

\section{Introduction}

Skin diseases are a common and significant cause of morbidity in Nepal. The annual report of the Department of health services in 2067/068 (2010/2011 A.D) ranks skin diseases as the fourth most common problem in patients attending outpatient clinics in the country, and comprises $1.4 \%$ of the total in-patient morbidity. ${ }^{1}$ According to the data of a referral hospital in Kathmandu, in the year 2008, skin diseases accounted 10.5\% $(34,360)$ of total out-patient department $(3,25,920) .^{2}$ However, a community study which surveyed a rural population of 3207 inhabitants showed an overall skin disease prevalence of 20.1 $\%{ }^{3}$ Information on community based prevalence and pattern of skin diseases would be a better measure of burden due to skin diseases in the general population in order to assist in planning of possible intervention strategies.

This study was done to determine the pattern of skin diseases in a rural village development community (VDC) of Nepal.

\section{Material and methods}

The study was conducted at Talku - Dudhechaur 
Vol. 12, No. 1, 2014

\section{Original Article}

VDC, a village community in Kathmandu district located $25 \mathrm{kms}$ south of the city. Two free dermatologic camps were conducted in the month of July 2011, at locations in the village convenient for most inhabitants to attend. All patients were examined by dermatologists and diagnoses made based on clinical features. The demographic and clinical data were recorded in a predesigned patient record form, which was analyzed using SPSS software package. Patients requiring further management were referred to tertiary hospitals in Kathmandu.

\section{Results}

There were 433 villagers examined and 359 had one or more skin diseases (camp prevalence$83 \%$ ). Among the 359 patients 172 (47.9\%) were males and $187(52.1 \%)$ were females. The age of patients ranged from 1 to 80 years (mean-24.5; $\mathrm{SD} \pm 15.9)$. Majority of our patients were adolescents (44\%), mostly students in the age group of 10-19 years (Figure 1).

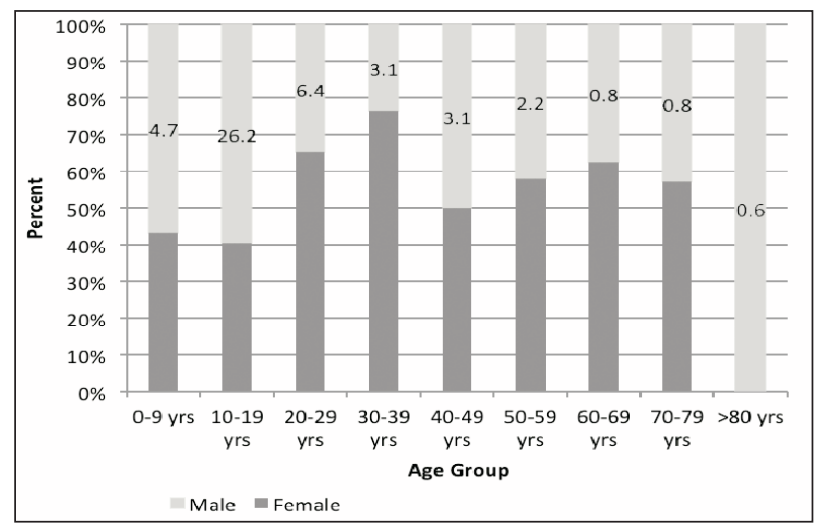

Figure 1: Age and gender distribution of patients

Out of 359 patients 275 of them had two or more skin diseases identified. Thus, there were 454 different skin disorders identified in 359 patients. The most common skin disease category were eczemas, followed by infections, acne, pigment disorders and urticaria. The percentages of skin disease categories and single skin diseases are shown in Table 1. The top five skin disease categories comprised $89 \%$ of the skin diseases diagnosed.
Table 1: Skin disease categories and single skin diseases

\begin{tabular}{|c|c|c|}
\hline Disease & $\begin{array}{l}\text { No. of } \\
\text { patients }\end{array}$ & $\%$ \\
\hline Eczemas & 131 & 28.9 \\
\hline Allergic contact dermatitis & 35 & 7.7 \\
\hline Pityriasis alba & 34 & 7.5 \\
\hline Irritant contact dermatitis & 29 & 6.4 \\
\hline Seborrheic dermatitis & 17 & 3.7 \\
\hline Chronic foot eczema & 7 & 1.5 \\
\hline Chronic hand eczema & 4 & 0.9 \\
\hline Lichen simplex chronicus & 2 & 0.4 \\
\hline Atopic dermatitis & 1 & 0.2 \\
\hline Numular eczema & 1 & 0.2 \\
\hline Chronic solar damage & 1 & 0.2 \\
\hline Infections & 102 & 22.5 \\
\hline Pyodermas & 24 & 5.3 \\
\hline Secondary pyoderma & 16 & 3.5 \\
\hline Impetigo & 4 & 0.9 \\
\hline Furuncle & 2 & 0.4 \\
\hline Folliculitis & 2 & 0.4 \\
\hline Viral infections & 23 & 5.1 \\
\hline Common warts & 18 & 4.0 \\
\hline Varicella & 3 & 0.7 \\
\hline Herpes labialis & 1 & 0.2 \\
\hline Molluscum contagiosum & 1 & 0.2 \\
\hline Fungal infections & 20 & 4.4 \\
\hline Pityriasis versicolor & 12 & 2.6 \\
\hline Tinea pedis & 3 & 0.7 \\
\hline Tinea capitis & 2 & 0.4 \\
\hline Tinea corporis & 2 & 0.4 \\
\hline Tinea cruris & 1 & 0.2 \\
\hline Infestations & 35 & 7.7 \\
\hline Scabies & 24 & 5.3 \\
\hline Insect bites & 11 & 2.4 \\
\hline Acne & 79 & 17.4 \\
\hline Mild acne & 50 & 11.0 \\
\hline Moderate acne & 23 & 5.1 \\
\hline Severe acne & 6 & 1.3 \\
\hline Pigment disorders & 48 & 10.6 \\
\hline Melasma & 32 & 7.0 \\
\hline Post-inflammatory hyperpigmentation & 7 & 1.5 \\
\hline Freckles & 5 & 1.1 \\
\hline Vitiligo & 4 & 0.9 \\
\hline Urticaria & 44 & 9.7 \\
\hline Acute & 6 & 1.3 \\
\hline Chronic & 38 & 8.4 \\
\hline Pruritus & 13 & 2.9 \\
\hline Generalised & 10 & 2.2 \\
\hline Localised & 3 & 0.7 \\
\hline Lumps/cysts & 4 & 0.9 \\
\hline Lipoma & 2 & 0.4 \\
\hline Sebaceous cyst & 2 & 0.4 \\
\hline Psoriasis & 3 & 0.7 \\
\hline Nevi & 3 & 0.7 \\
\hline Others & 27 & 5.9 \\
\hline TOTAL & 454 & 100.0 \\
\hline
\end{tabular}

NJDVL - 42 


\section{Original Article}

There were 131 patients with eczema, and the most common forms were allergic contact dermatitis, pityriasis alba and irritant contact dermatitis. The most common type of infection was pyodermas followed by viral infections in which warts were the most common, identified in 18 individuals. Superficial fungal infections were also common where pityriasis versicolor was identified in the majority and few dermatophytoses. Acne was identified in 79 individuals with 6 of them suffering from severe acne. Melasma was the most common pigment disorder and vitiligo was seen in 4 individuals. Chronic urticaria was more common than acute form.

\section{Discussion}

Skin diseases are common and pose a significant burden to health resources in many developing countries. It is also one of the commonest reasons for seeking healthcare services in Nepal. Determining the pattern of skin diseases in the community is essential to make a better assessment of the situation in the general population. One of the early publications on skin diseases in Nepal reports pyodermas, eczematoid dermatitis, insect bite reactions, tinea infections, infestations such as scabies, melasma and acne as commonly occurring skin conditions among out-patients. ${ }^{4}$ Shrestha DP et. al surveyed a rural hilly community in central Nepal with 3207 inhabitants and reported an overall prevalence of $20.1 \%$ with the most common SD categories being eczemas, followed by pigment disorders, acne, urticaria and moles and lumps. Our study similarly shows a commoner trend of eczemas, acne and pigment disorders. Most of our patients engage in farming for their livelihood and works routinely in the farms with little protection from the sun or other potential environmental insult. They are thus more prone to develop various forms of allergic and irritant contact dermatitis mainly of the hands and feet. The common nepali skin type (Fitzpatrick's type III and IV) also tans more easily resulting in various forms of pigment disorders either induced or aggravated by ultraviolet exposure. Melasma was the most common pigment disorder which can be attributed to repeated exposure to ultraviolet rays in addition to racial factors and genetic predisposition. Infectious skin conditions including pyogenic infections, viral and fungal infections alongwith infestations were seen in 102 individuals (22.5\%). A slightly higher prevalence of such infectious diseases has been reported from mountainous north india (33\%) but much higher prevalence has been reported from other Asian countries and Africa. ${ }^{5-9}$ We identified 35 individuals with infestations including 24 with scabies and 11 with insect bites. Although such infestations are a common occurrence in our rural population, a study from rural Egypt reports it as the commonest skin condition $(27.4 \%)$ with pediculosis capitis $(19.37 \%)$ being the commonest. ${ }^{10}$ Studies from India have reported pediculosis capitis more commonly in children $(47.1 \%) .{ }^{11}$ We did not record any case of pediculosis in our study. This could be attributed to differences in several climatic and life-style factors which determine clothing habits, living conditions such as overcrowding as well as maintenance of hygiene.

\section{Conclusion}

Skin diseases are common in the community. Eczemas, infections, acne and pigment disorders are the more common conditions. Larger population based surveys along with assessment of impact on quality of life are essential to determine the burden of skin diseases in the general population.

Acknowledgement: We would like to thank the health workers Urmila Balami and Roshna Balami for helping us conduct the camp. We are grateful to the villagers of Talku village for their cooperation. 


\section{Original Article}

\section{References}

1. Annual Report. Department of Health Services 2087/68 (2010/2011), Nepal.

2. Shrestha R, Kayastha BMM, Burathoki K. Glimpse of Dermatology OPD, Bir Hospital. Souvenir, Bir Hospital 2009; 33-4.

3. Shrestha DP, Gurung D, Rosdahl I. Prevalence of skin diseases and impact on quality of life in hilly region of Nepal. JIOM 2012; 34: 44-9.

4. Burgoyne JS. Dermatology in Nepal. Int J Dermatol 1974; 13: 104-6.

5. Grills N, Grills C, Spelman T, Stoove M, Hellard M, El-Hayek C et. al. Prevalence survey of dermatologic conditions in mountainous north India. Int J Dermatol 2012; 51: 579-87.

6. Saw SM, Koh D, Adjani MR, Wong ML, Hong $\mathrm{CY}$, Lee J et.al. A population-based prevalence survey of skin diseases in adolescents and adults in rural Sumatra, Indonesia, 1999. Trans R Soc
Trop Med Hyg 2001; 95: 384-8.

7. Mahe A, Cisse IA, Faye O, N'Diaye HT, Niamba P. Skin diseases in Bamako (Mali). Int J Dermatol 1998; 37: 673-6.

8. Mahe A, N'Diaye HT, Bobin P. The proportion of medical consultations motivated by skin diseases in the health centers of Bamako (Republic of Mali). Int J Dermatol 1997; 36: 185-6.

9. Henderson CA. Skin disease in rural Tanzania. Int J Dermatol 1996; 35: 640-2.

10. Abdel-Hafez K, Abdel-Aty MA, Hofny ERM. Prevalence of skin diseases in rural areas of Assuit Governorate, Upper Egypt. Int J Dermatol 2003; 42: 887-92.

11. Saurabh S, Sahu SK, Sadishkumar A, Kakkanattu JC, Prapath I, Ralte L et. al. Screening of skin diseases among primary school children in a rural area of Pondicherry. Indian J Dermatol Venereol Leprol 2013; 79: 268. 